\title{
Quarantine lessons from islands to airports
}

\author{
Quarantine: What is Old is New \\ Halifax and the Lawlor's Island \\ Quarantine Station: 1866-1938 \\ Ian Arthur Cameron MD \\ New World Publishing; 2007 \\ 206 pp \$19.95 ISBN 13 978-1-895814-34-7
}

$\mathrm{T}$ his timely book documents the choppy development, fluctuating function and eventual abandonment of Lawlor's Island, a quarantine station in Halifax Harbour in Nova Scotia. It was 1 of 4 major maritime quarantine stations servicing shipping traffic on the Atlantic Coast of Canada over the period 1866-1938 - a period that encompassed the Confederation of Canada, as well as massive immigration, the discovery of the smallpox vaccine, the Spanish influenza, the Great World Wars and several other determinants of public health.

On first blush the thin volume, awkward fonts and quaint maps of Dr. Ian Campbell's text are charmingly deceptive. The whole package in hand feels and looks a bit like a scrapbook that invites sampling, flipping and occasional exploration. This is certainly an option for the hungry reader looking for a quick snack and break. But if I can, as a public health officer, whet your appetite for a more complete and balanced diet, then please join the slow food movement and linger over this full course meal, for the sake of your health — and ours.

Look at the meticulous index and logical chronology of the chapters, pieced together with undertones of discipline and passion. The prologue tugs together and compiles seemingly disparate chapters on the emerging Canadian and global conscience about contagions, the toll of smallpox and cholera, the scientific requisites for disinfection and social isolation and the pragmatic, engineering mechanics of island life that ensure, amid fog and salt, potable water and safe transport.

Woven between the warp and weft of this infrastructure lie the stray threads that appeal to discrete readers: the shortcom-

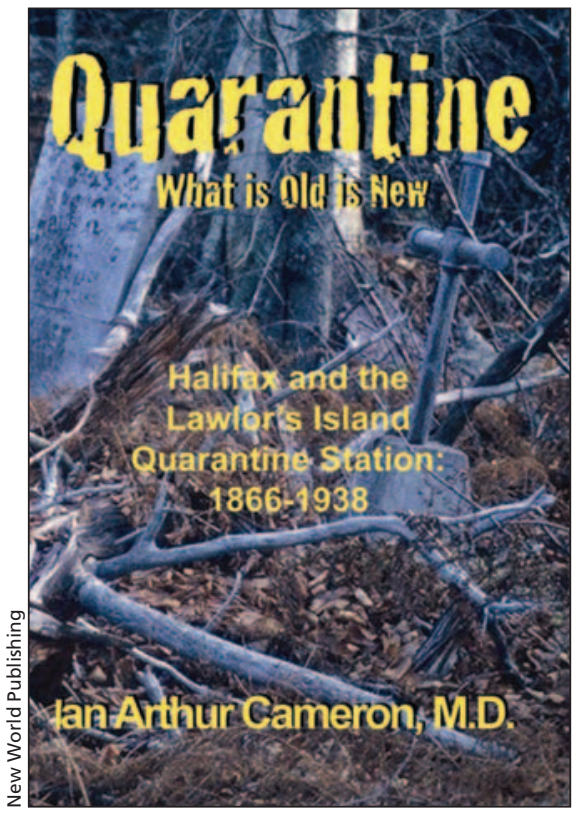

ings of individual personalities, pictures of old ships, the history of Canada's immigrants, the transitory presence and diary of Leo Tolstoy's son on our soil and the sad, revealing fate of individual decisions and political aspirations.

On even closer inspection, those of us affected by SARS will identify recurring themes about our system's habit

\section{Osler quotes redux}

The Quotable Osler Deluxe Edition Mark E. Silverman, T. Jock Murray, Charles S. Bryan, editors; $\$ 89.95$

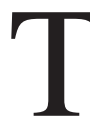
his deluxe release of the 2003 paperback "repository of Oslerian sound bites" (CMAJ 2003;168:745-6), at twice the price, is clearly designed and timed to sell, perhaps as a presentation to the graduate or recently promoted. Leather binding, gold print and edging and a ribbon bookmark give it that authentic look. Marbled endpaper completes the luxurious effect.

For the scholar of Osleriana, what is and capacity to respond to the threat of contagion. I counted 50 in this book, of which I will only touch on a few: the sluggishness of bureaucracy, the heroism of individual health professionals, the shortcomings of political patronage and the memory lapses of all of us.

So, to whom might this book appeal? Perhaps to medical officers of health. To hospital staff that handled SARS. To medical historians. To any of us whose family arrived at this homeland by boat. To those of us who anticipate the influenza pandemic.

And to whom might it not appeal? Perhaps to one particular Canadian minister of health who experienced, on the provincial level, the impact of SARS, and who now oversees our international airports where dismally few federal quarantine officers wait on call for the next ship to dock at the air-port, lest he be reminded.

\section{Erica Weir MD}

Associate Professor

Department of Community Health and Epidemiology

Queen's University

Kingston, Ont. new here is the recent discovery at McGill's Osler Library of a handwritten address to entering medical students in Philadelphia in 1885. From it "forty eloquent remarks" have been added, as well as 10 from other sources. Which these are and where they occur is left unclear. However, on page 32, one reads the first of the Philadelphia quotes and learns that the address was published privately by the Osler Library in 2006. Also featured are "neverbefore-published "photographs, though, again, which these are is not stated. (I could find only 3 that I do not recall seeing in other publications). Still, it is a lovely book if you're looking for a special treat for someone. - Ken Flegel MDCM MSc, CMAJ 